\title{
A Review of Possible Causes of Nutrient Enrichment and Decline of Endangered Sucker Populations in Upper Klamath Lake, Oregon
}

\section{U.S. GEOLOGICAL SURVEY}

Water-Resources Investigations Report 93-4087
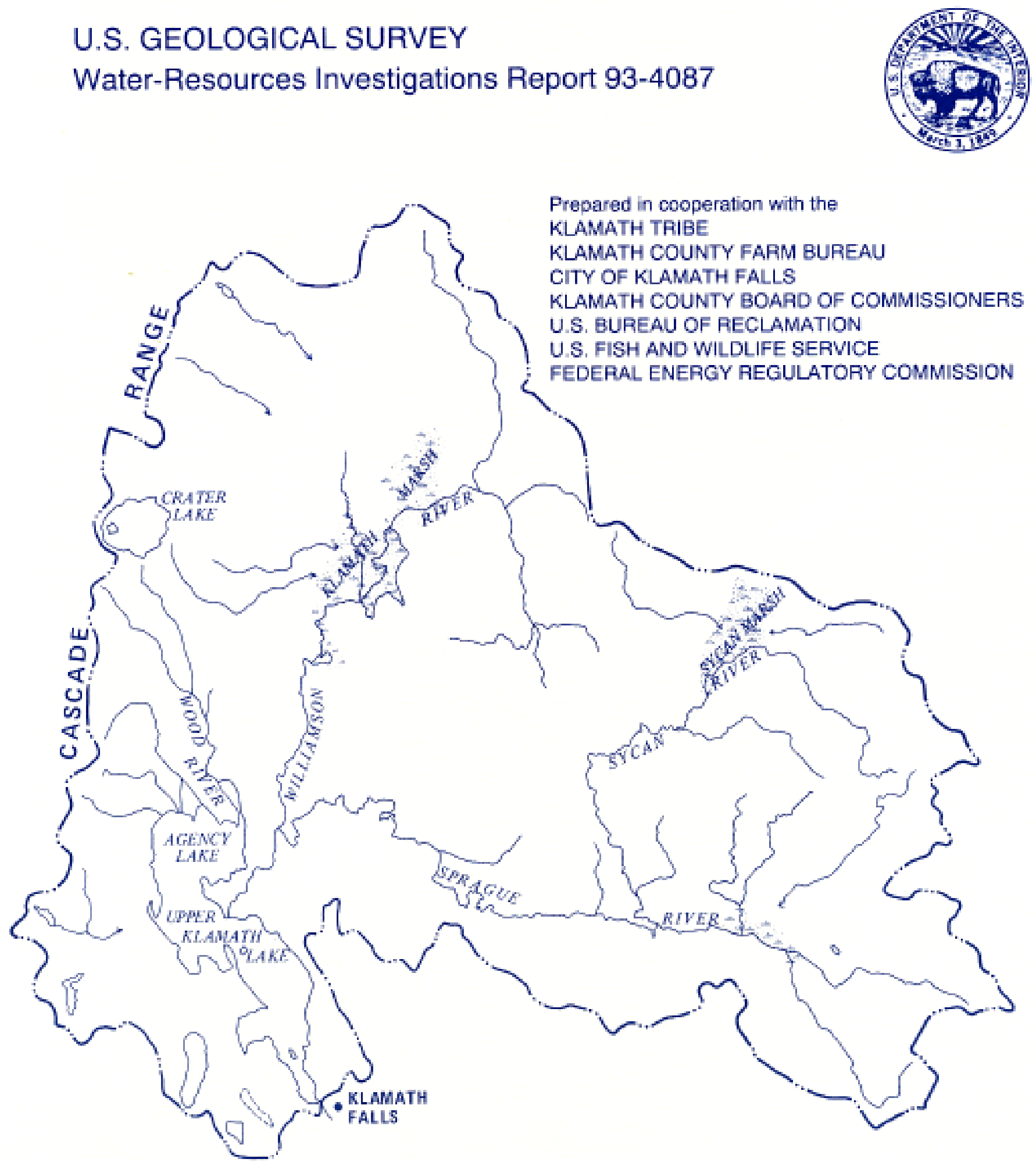
A Review of Possible Causes of Nutrient Enrichment and Decline of Endangered Sucker Populations in Upper Klamath Lake, Oregon 


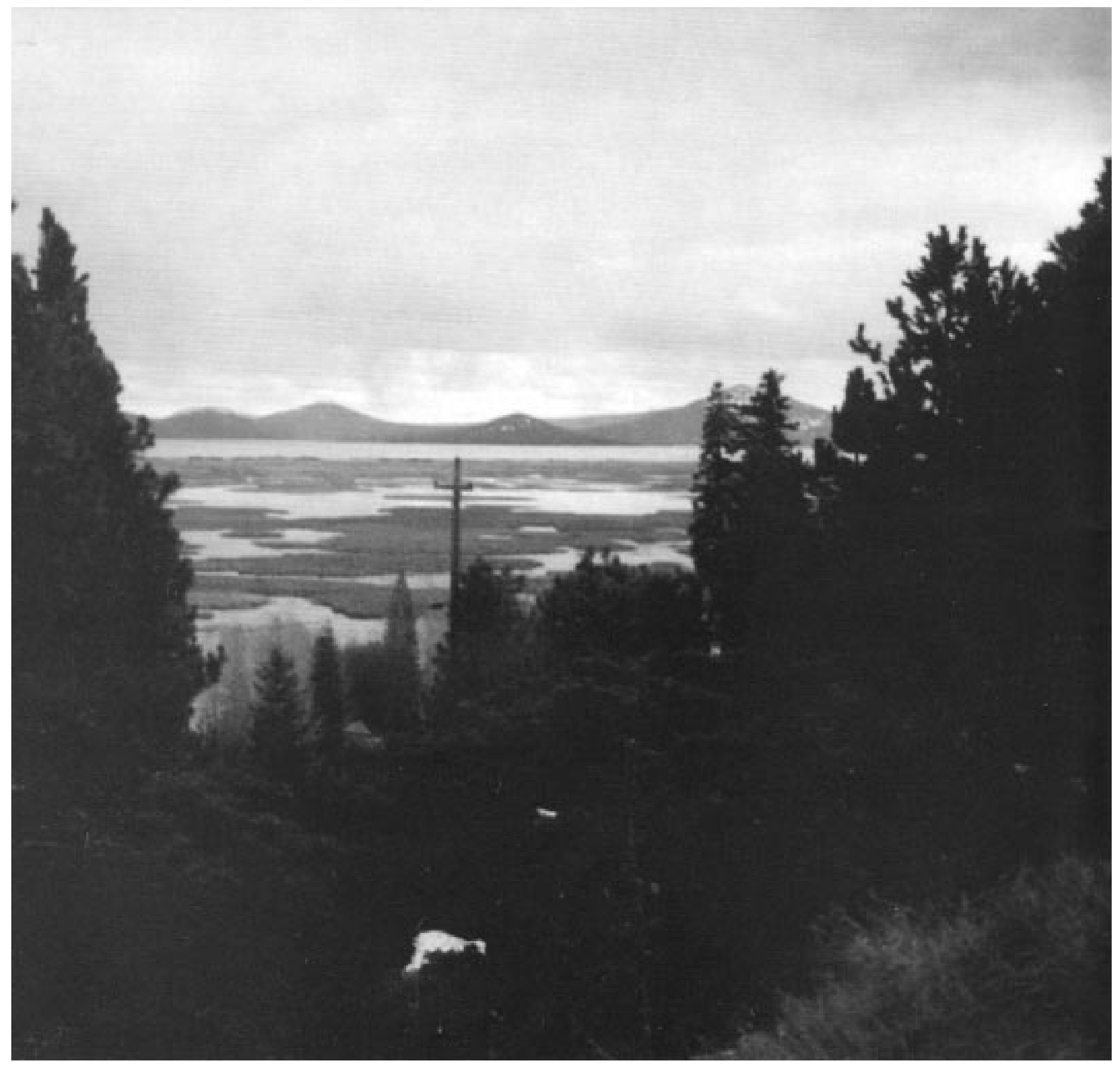

Frontispiece. Upper Klamath Lake and Upper Klamath National Wildlife Refuge (foreground) looking east from county road 531 (photograph by Howard Harrison, February 1992). 


\title{
A Review of Possible Causes of Nutrient Enrichment and Decline of Endangered Sucker Populations in Upper Klamath Lake, Oregon By Gilbert C. Bortleson and Marvin O. Fretwell
}

\author{
U.S. GEOLOGICAL SURVEY \\ Water-Resources Investigations Report 93-4087 \\ Prepared in cooperation with the \\ KLAMATH TRIBE \\ KLAMATH COUNTY FARM BUREAU \\ CITY OF KLAMATH FALLS \\ KLAMATH COUNTY BOARD OF COMMISSIONERS \\ U.S. BUREAU OF RECLAMATION \\ U.S. FISH AND WILDLIFE SERVICE \\ FEDERAL ENERGY REGULATORY COMMISSION
}




\title{
U. S. DEPARTMENT OF THE INTERIOR BRUCE BABBITT, Secretary
}

\author{
U.S. GEOLOGICAL SURVEY
}

ROBERT M. HIRSCH, Acting, Director

For additional information

write to:

District Chief

U.S. Geological Survey, WRD

10615 S.E. Cherry Blossom Drive

Portland, Oregon 97216
Copies of this report can

be purchased from:

U.S. Geological Survey

Earth Science Information Center

Open-File Reports Section

Box 25286, MS 517

Denver Federal Center

Denver, Colorado 80225 


\section{CONTENTS}

Abstract

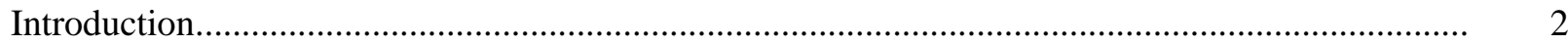

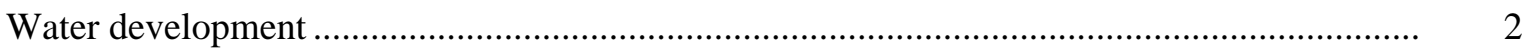

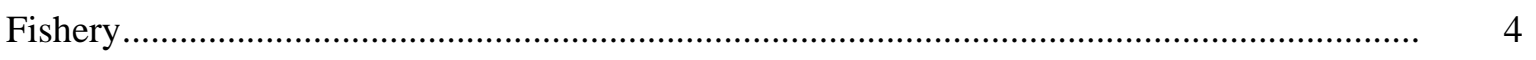

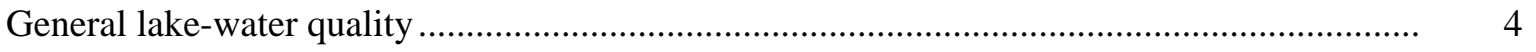

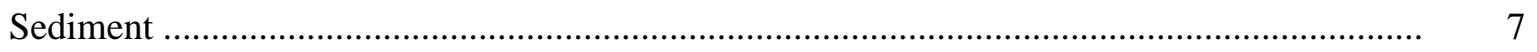

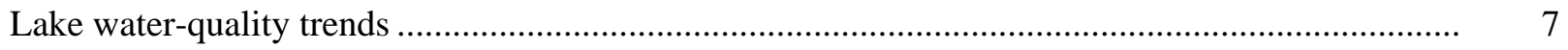

Possible causes of excessive nutrient enrichment in Upper Klamath Lake.................................... 8

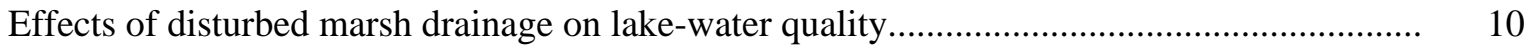

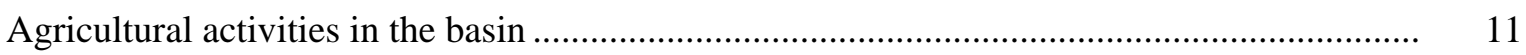

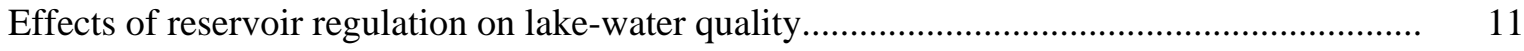

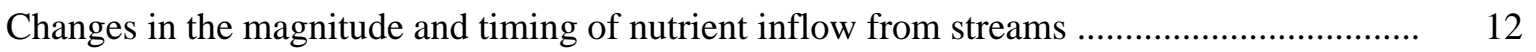

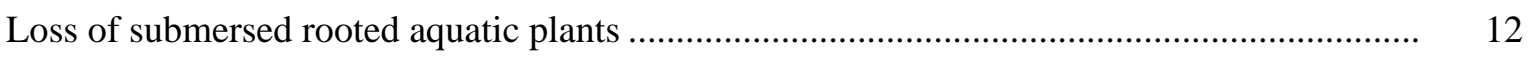

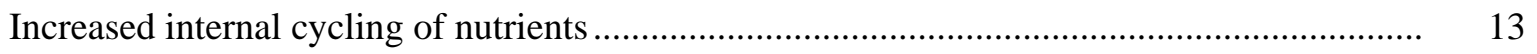

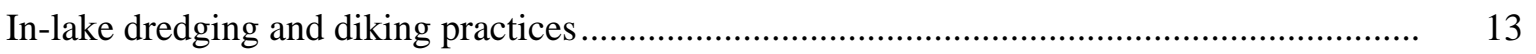

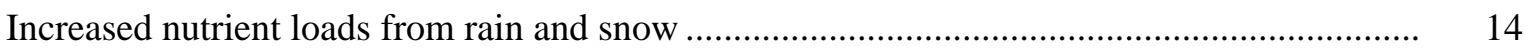

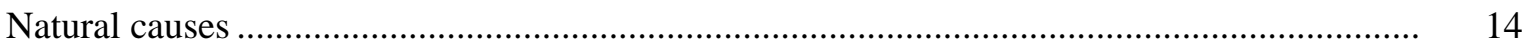

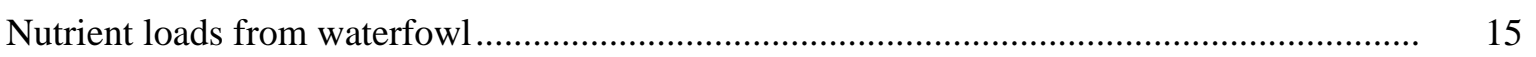

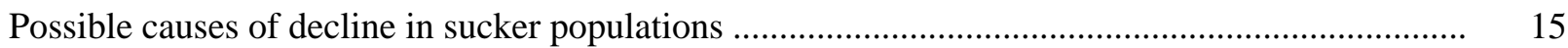

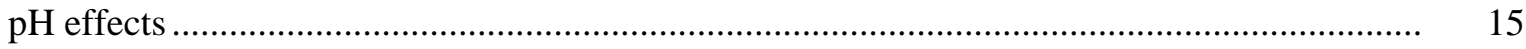

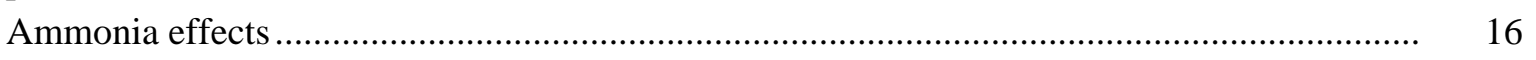

Hypoconcentrations or hyperconcentrations of dissolved oxygen ........................................ 17

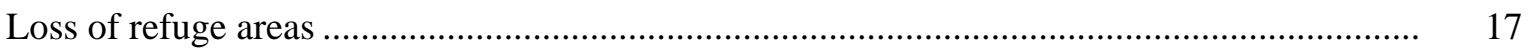

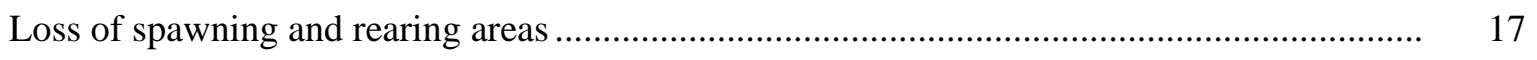

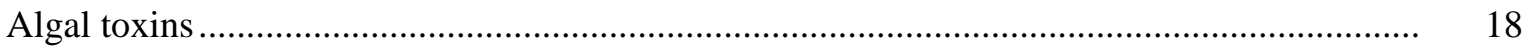

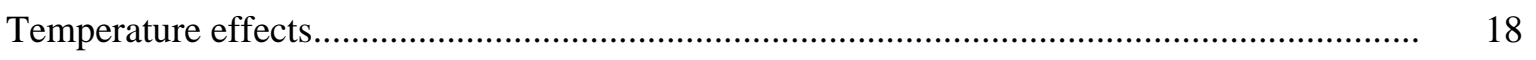

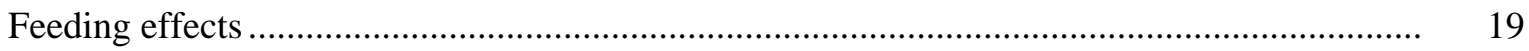

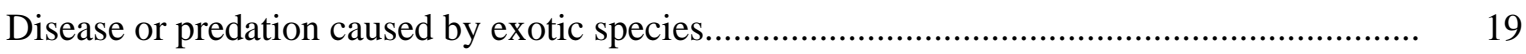

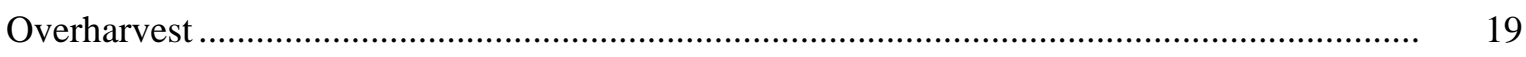

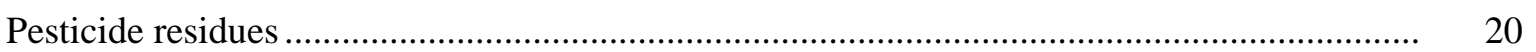

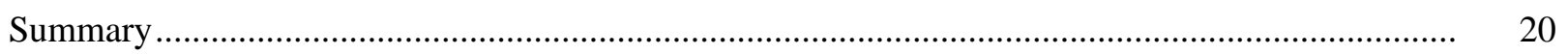

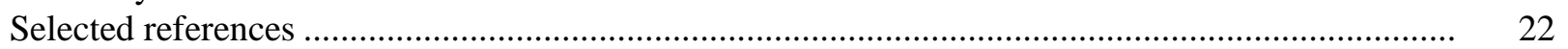




\section{ILLUSTRATIONS}

Figure

1. Map showing Upper Klamath Lake Basin and vicinity

2. Map showing Upper Klamath Lake and surrounding marsh in the early 1900 's

\section{TABLES}

Tables

1. Concentrations of total ammonia and total soluble phosphorus in sediment pore water from Upper Klamath Lake.

2. Historical changes in algal populations in Upper Klamath Lake. 


$\begin{array}{lcc}\text { foot }(\mathrm{ft}) & 0.3048 & \text { meter } \\ \text { square foot }\left(\mathrm{ft}^{2}\right) & 0.0929 & \text { square meter } \\ \text { mile }(\mathrm{mi}) & 1.609 & \text { kilometer } \\ \text { square mile }\left(\mathrm{mi}^{2}\right) & 2.590 & \text { square kilometer }\end{array}$

Temperature: Air temperatures are given in degrees Fahrenheit $\left({ }^{\circ} \mathrm{F}\right)$, which can be converted to degrees Celsius $\left({ }^{\circ} \mathrm{C}\right)$ by the following equation:

$$
{ }^{\circ} \mathrm{C}=5 / 9\left({ }^{\circ} \mathrm{F}-32\right)
$$

Following convention, water temperatures are given in degrees Celsius, which can be converted to degrees Fahrenheit by the following equation:

$$
{ }^{\circ} \mathrm{F}=1.8\left({ }^{\circ} \mathrm{C}\right)+32
$$

Sea Level: In this report "sea level" refers to the National Geodetic Vertical Datum of 1929 (NGVD of 1929)--a geodetic datum derived from a general adjustment of the first-order level nets of both the United States and Canada, formerly called "Sea Level Datum of 1929"

Chemical concentrations are given in metric units as milligrams per liter $(\mathrm{mg} / \mathrm{L})$ or micrograms per liter $(\mu \mathrm{g} / \mathrm{L})$. Milligrams per liter is a unit expressing the concentration of chemical constituents in solution as weight (milligrams) of solute per unit volume (liter) of water. One milligram per liter is equivalent to one thousand micrograms per liter. For concentrations less than about 7,000 $\mathrm{mg} / \mathrm{L}$, the numerical value is the same as for concentrations in parts per million. Micrograms per liter are equivalent to parts per billlion. 


\title{
A Review of Possible Causes of Nutrient Enrichment and Decline of Endangered Sucker Populations in Upper Klamath Lake, Oregon
}

\author{
By Gilbert C. Bortleson and Marvin O. Fretwell
}

\begin{abstract}
Upper Klamath Lake, and the connecting Agency Lake, is a large (140 square mile) lake in south-central Oregon. The lake has a recent history of long-duration, near-monoculture, blue-green algal blooms of Aphanizomenon flos-aquae. Typically, the algal bloom causes nuisance and detrimental conditions, including a deep-green "pea soup" appearance, from mid-May to late October. Accompanying the blooms are foul odors, extremely high $\mathrm{pH}$, widely varied dissolved-oxygen concentrations of supersaturation or near depletion, occasional but extensive fish kills, and elevated levels of toxic ammonia. In 1988, the Lost River sucker (Deltistes luxatus) and shortnose sucker (Chasmistes brevirostris), long-term inhabitants of Upper Klamath Lake, were placed on the Federal endangered-species list. The endangering of the sucker species in recent years is hypothesized to be caused by degraded lake-water-quality conditions.

Upper Klamath Lake has been eutrophic since it was first discovered. However, increases in algal abundance and changes in algal type over relatively recent years are evident, and can be correlated with agricultural development of the basin. The most common cause for an increased abundance of algae in lakes is increased enrichment of nitrogen and phosphorus compounds.

Ten possible causes for this excessive enrichment in nutrients are described. Three of these hypotheses are suggested for immediate testing because of large-scale changes in nutrient loading that may have occurred as a result of man's activities. These three hypotheses relate nutrient enrichment to (1) conversion of marshland to agricultural land, (2) agricultural drainage from the basin, and (3) reservoir regulation. Eleven possible hypothetical causes for the decline in sucker populations also are described. The decline in sucker population may be related to excessive nutrient enrichment (eutrophication) of the lake.
\end{abstract}




\section{INTRODUCTION}

Upper Klamath Lake, and the connecting Agency Lake, is the second largest lake in Oregon, and is one of the largest water bodies in the Western United States (Bue, 1963). For purposes of subsequent discussion, Upper Klamath Lake will be understood to include Agency Lake. Upper Klamath Lake has a shallow mean depth of 8 feet, in proportion to its large surface area of 90,000 acres $\left(140 \mathrm{mi}^{2}\right.$ [square miles]). The lake is located in a large, flat valley flanked by steep hills and mountains in south-central Oregon (fig. 1). The entire valley was formerly occupied by a Pleistocene-age lake. Much of the basin is in mountainous terrain covered with volcanic pumice deposits derived from the explosive eruption of Mount Mazama about 6,800 years ago. The principal tributaries to the lake are the Williamson and Wood Rivers (fig. 1). The Williamson River is the largest; much of its flow derives from its major tributary, the Sprague River (fig. 1). In addition to streams, spring flow and ground-water seepage provide continuous inflow to the lake throughout the year. Water leaving Upper Klamath Lake drains southwestward to California and ultimately to the Pacific Ocean.

For approximately 50 years, the lake has a history of long duration, near monoculture, blooms of the blue-green alga, Aphanizomenon flos-aquae (A. flos-aquae). This abundant algal production, usually occurring from mid-May to late October, causes nuisance and detrimental conditions including a deep-green "pea soup" appearance, foul odors, extremely high pH, severe and widespread dissolved-oxygen supersaturation or depletion, wide fluctuations of carbon dioxide concentration, elevated levels of toxic ammonia, and occasional extensive fish kills. In addition to the mortality of adult fish, larval and juvenile suckers also are affected (Coleman and others, 1988). Bienz and Ziller (1987) reported that Lost River suckers (Deltistes luxatus) and shortnose suckers (Chasmistes brevirostris) appear headed for extirpation from Upper Klamath Lake. These two sucker species were listed as endangered species in the Federal Register (July 18, 1988). The Klamath largescale sucker (Catostomus snyderi) appears to be the only healthy sucker population in the lake (Bienz and Ziller, 1987), although the authors did express concern for the status of Klamath largescale sucker populations. The Klamath largescale sucker is on the U.S. Forest Service sensitive species list for Upper Klamath Lake and its major tributaries. Water-quality data collected by Coleman and others (1988) indicated that conditions in Upper Klamath Lake would be highly stressful and potentially lethal to fish. Recent concerns with sucker survival in the lake have caused the Klamath Tribe to construct a hatchery facility on the Sprague River (fig. 1) to sustain future propagation of the species while the problem is being studied and a long-term solution is found.

The U.S. Geological Survey (USGS) in cooperation with the Klamath Tribe and several Federal, State, and local agencies developed a phased study to assess eutrophication and water-quality problems important to sucker survival. Ten possible hypothetical causes are described as to why the lake has become excessively enriched with nutrients and 11 hypotheses as to why sucker species have declined. The purpose of this report is to discuss hypotheses for possible testing and to provide an approximate priority for testing. The overall objective is to provide a focus for future study and prioritization for study with limited resources available.

\section{Water Development}

Upper Klamath Lake is a principal source of water supply for irrigated lands in the lower Klamath Basin. The lower Klamath Basin, near the Oregon-California border (fig. 1), was one of the earliest Federal reclamation projects developed for agriculture. In 1905, construction was authorized to drain and reclaim lakebed lands of Lower Klamath and Tule Lakes. Link River Dam on Link River, at the head of the Klamath River and just west of Klamath Falls, 


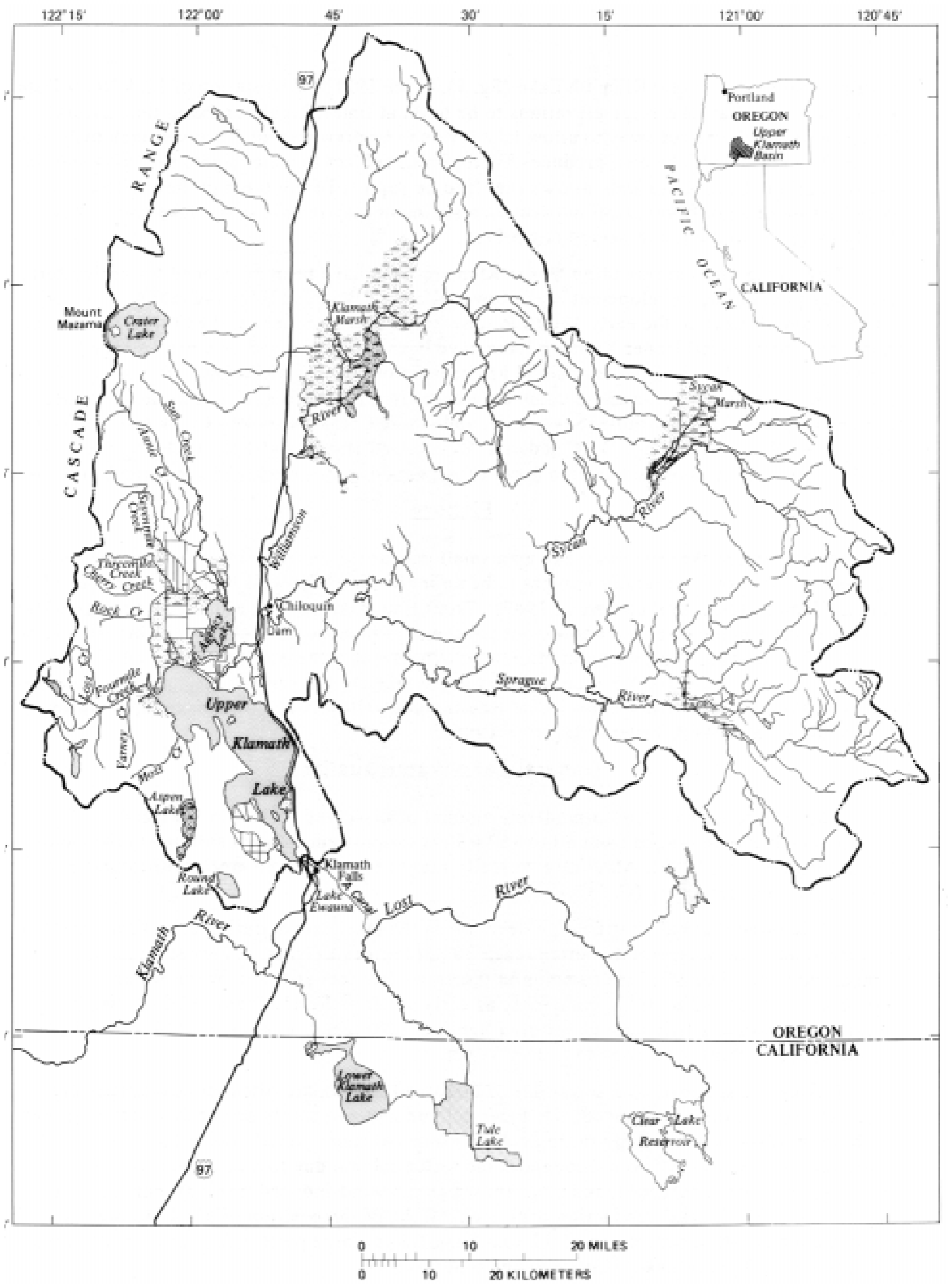

Figure 1.-Upper Klamath Lake Basin and vicinity. 
regulates flow from Upper Klamath Lake (fig. 1). Since 1921, the operation of Link River Dam has caused seasonal lake-stage elevations to be both, at times, higher or lower than natural levels; a rock sill was cut away to allow lake levels to be drawn about $3 \mathrm{ft}$ lower than historical levels. The regulated lake also produces hydropower, subject to water rights for irrigation. In the springtime, Link River Dam allows runoff to be captured from the high flows. Thus, after construction of Link River Dam, nutrient-rich sediment may remain in the lake and is less likely to be scoured out and passed downriver.

Low-lying areas surrounding Upper Klamath Lake have been developed for agriculture, generally post-dating development in the lower Klamath Basin. The marsh that surrounded Upper Klamath Lake in the early 1900's is shown in figure 2. Since the 1930's, large areas of marsh that surrounded Upper Klamath Lake have been diked, ditched, and drained for agricultural use. Much of the marshland has been converted to pastureland for grazing of cattle. Areas of higher ground are commonly cultivated for crops such as hay and potatoes. Land is irrigated from Fourmile, Sevenmile, and Annie Creeks, Crooked Creek (not shown on figure), and Wood River (fig. 1). Caledonia, Wocus, and Hanks marshes, bordering the southern part of the lake, and an area north of Algoma have been drained for agricultural use.

\section{Fishery}

At present, sucker species make up a small part of the entire fish population, but their survival in the lake is generally thought to be an indicator of the well-being of other fish ( $\mathrm{J}$. Kann, Klamath Tribe, oral commun., 1989). Trout also make up only a small percentage of the fish population in the lake. Rainbow trout are common in most areas of the lake in fall, winter, and spring; but in summer, the trout migrate to tributary mouths and springs (Bond and others, 1968). The most abundant fish species found in the lake are fathead minnows and Blue and Tui chubs. Other common fish species in the lake include yellow perch, sculpins, and lamprey (Bond and others, 1968; Federal Register, 1988).

\section{General Lake-Water Quality}

The lake contains a low-to-moderate amount of dissolved solids. In 1981 and 1982, specific conductance ranged from 80 to $150 \mu \mathrm{S} / \mathrm{cm}$ (microsiemens per centimeter) [Klamath Consulting Service, 1983]. Alkalinity typically ranges from 50 to $80 \mathrm{mg} / \mathrm{L}$ (milligrams per liter) as calcium carbonate $\left(\mathrm{CaCO}_{3}\right)$.

Little or no thermal stratification develops in the lake, except during calm sunny periods. Summertime water temperatures often reach $30^{\circ} \mathrm{C}$ (degrees Celsius) at near surface, and temperatures of 22 to $24^{\circ} \mathrm{C}$ are common in the upper few feet of water. When water temperatures reach 12 to $15^{\circ} \mathrm{C}$, commonly as early as May, the dominant algal species is usually A. flos-aquae (Klamath Consulting Service, 1983), and remains so until November (J. Kann, Klamath Tribe, oral commun., July 1989).

During the summer, concentrations of dissolved oxygen are often photosynthetically supersaturated in the upper part of the water column and commonly drop below $2.0 \mathrm{mg} / \mathrm{L}$ near the bottom of the water column during calm periods. At times, small concentrations of dissolved oxygen are observed throughout the water column due to a combination of high temperature, algal senescence, and stagnant water (no wind-induced mixing). For example, on September 1, 1987, algal production declined, and the decomposition of algal biomass caused oxygen-concentration reductions of 0.2 to $5.3 \mathrm{mg} / \mathrm{L}$ over large parts of Upper Klamath Lake (not including Agency Lake) [Coleman and others, 1988]. 


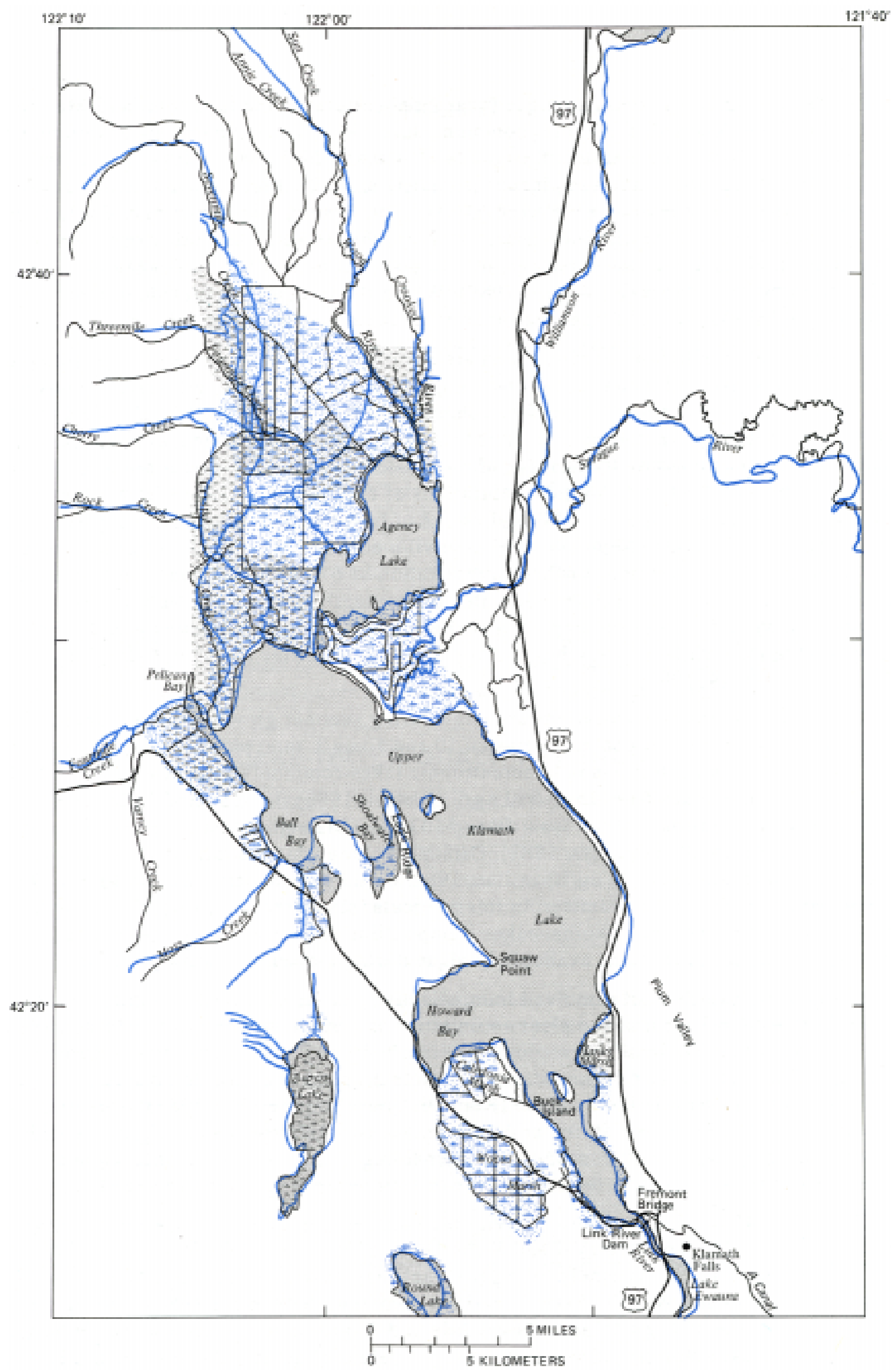

Figure 2.-Upper Klamath Lake and surrounding marsh in the early 1900's.

Blue shows early marsh and stream locations (from Gilbert, 1928). 
A. flos-aquae is the dominant algae (near monoculture) in the lake from mid-May to late October (J. Kann, Klamath Tribe, oral commun., July 1989). During midsummer bloom, cells of A. flos-aquae float to the surface, forming thick scums which vary in density and lake location. The actual distribution of algae is primarily dependent on the wind, which causes the scums to shift in the direction of the wind. On July 19, 1989, a thick scum near Eagle Ridge (fig. 2) resulted in a Secchi disc measurement of less than $0.3 \mathrm{ft}$, while other open-water areas in the lake had Secchi disc measurements of 2 to $3 \mathrm{ft}$ (S. Campbell, U.S. Bureau of Reclamation, written commun., August 1989). Where thick scums are prevalent, a point is reached where self-shading or light inhibits further increases in productivity.

Summer chlorophyll $a$ concentrations are usually large. The biomass of A. flos-aquae, expressed by chlorophyll $a$ concentrations, ranged from 127 to $1,040 \mu \mathrm{g} / \mathrm{L}$ (micrograms per liter) for particles greater than $25 \mu \mathrm{m}$ (micrometers) in size on July 19, 1989 (S. Campbell, U.S. Bureau of Reclamation, written commun., August, 1989). For comparison, concentrations of chlorophyll $a$ in excess of $10 \mu \mathrm{g} / \mathrm{L}$ are often considered indicative of eutrophic lakes (Rast and Lee, 1978). In 1981 and 1982, concentrations of chlorophyll $a$ ranged from a low of $2 \mu \mathrm{g} / \mathrm{L}$ in December to a high of $1,400 \mu \mathrm{g} / \mathrm{L}$ in June. In 1987, excluding a site near Pelican Bay (fig. 2), the average June to September chlorophyll $a$ concentration was $102 \mu \mathrm{g} / \mathrm{L}$ (Coleman and others, 1988). A maximum surface concentration of $671 \mu \mathrm{g} / \mathrm{L}$ was found in Howard Bay (fig. 2). Coleman and others (1988) noted that differences between sites were mainly dependent on wind direction and degree of sheltering. In 1987, A. flos-aquae was the dominant phytoplankton through late November, but was nearly gone in the December sampling (Coleman and others, 1988).

Total phosphorus concentrations are large during summer growing season. Most uncontaminated fresh water contains between 10 and $50 \mu \mathrm{g} / \mathrm{L}$ total phosphorus (Wetzel, 1983). Total phosphorus concentrations in hypereutrophic lakes commonly range from 750 to 1,200 $\mu \mathrm{g} / \mathrm{L}$, and eutrophic lakes from 16 to $390 \mu \mathrm{g} / \mathrm{L}$ (Wetzel, 1983). In 1981 and 1982, total phosphorus concentrations ranged from 50 to $510 \mu \mathrm{g} / \mathrm{L}$ (Klamath Consulting Service, 1983; and U.S. Army Corp. of Engineers, 1982). Orthophosphorus concentrations were below detectable concentrations $(<20 \mu \mathrm{g} / \mathrm{L})$ in June 1981, but large concentrations of 30 to $270 \mu \mathrm{g} / \mathrm{L}$ were observed the rest of the summer. In this particular study, the relatively high analytical detection limits for orthophosphorus makes it impossible to determine the lower range of orthophosphorus concentrations available to algae during the summer growing period.

Large concentrations of dissolved inorganic nitrogen are observed in winter, when large inflows from tributaries occur and plant assimilation is low. In the winter of 1981 and 1982, concentrations of ammonia nitrogen commonly reached 1 to $2 \mathrm{mg} / \mathrm{L}$, and nitrate nitrogen reached 0.15 to $0.20 \mathrm{mg} / \mathrm{L}$. Concentrations of nitrate dropped to below detectable levels in midsummer due to assimilation by algae (Klamath Consulting Service, 1983). Ammonia concentrations also decreased during midsummer, but concentrations were highly variable spatially and temporally, with concentrations remaining large at times. A. flos-aquae, however, can fix nitrogen from the atmosphere to fulfill its nitrogen requirements.

During times of high algal productivity the lake $\mathrm{pH}$ is often between 9 and 10 . High $\mathrm{pH}$ values result from the rapid removal and assimilation of dissolved $\mathrm{CO}_{2}$ (carbon dioxide) from the water by algae. These extremely high $\mathrm{pH}$ values may have an effect on fish survival (M. Coleman, U.S. Fish and Wildlife Service, written commun., September 1988). During the summer of 1987, the average pH throughout July and August at nine sites was 10. In bioassay tests, juvenile sucker mortality was observed at $\mathrm{pH}$ values of 10 and above (J. Kann, Klamath Tribe, oral commun., September 1988). 


\section{Sediment}

The bottom sediment in Upper Klamath Lake is predominantly silty clay that is neutral to slightly acidic, noncalcareous, uniform in texture, and composed of diatoms and organic matter, as well as clay minerals (Martin and Rice, 1981). The moisture content is high and uniform, ranging from 85 to 92 percent near the top. Bottom sediment begin to resuspend into the lower $3 \mathrm{ft}$ of the water column when wind velocities are greater than 2 to $5 \mathrm{mi}$ per hour (Bond and others, 1968). Algal growth is promoted by nutrients released from resuspended sediment to the overlying water. Except for isolated areas in the lake, such as Pelican Bay and Shoalwater Bay (fig. 2), the lake bottom is generally free of macrophyte growth (J. Kann, Klamath Tribe, oral commun., July 1989).

Gahler and Sanville (1971) found large concentrations of total soluble phosphorus $(0.40$ to $11.2 \mathrm{mg} / \mathrm{L}$ ) and ammonia $(2.3$ to $86 \mathrm{mg} / \mathrm{L})$ in pore water of Howard Bay bottom sediment (table 1; fig. 2). Smaller concentrations of total soluble phosphorus and ammonia were found in pore water of bottom sediment near Buck Island (table 1; fig. 2). Gahler and Sanville (1971) suggest that not all nutrients coming into the lake water through the bottom sediment result from direct recycling of deposited sediment. Indeed, large nutrient concentrations from local ground water infiltrating peaty soils could be entering the lake as ground-water flow, which would be present in the sediment pore water.

Concentrations of phosphorus in the regional ground water are large. Miller and Tash (1967) indicated a range of 0.05 to $0.24 \mathrm{mg} / \mathrm{L}$ total phosphorus from springs feeding the lake. Marsh sediment may retain phosphorus differently depending on hydrologic conditions and overlying soil material.

\section{LAKE WATER-QUALITY TRENDS}

The major problem encountered in attempting to establish water-quality trends in Upper Klamath Lake is the lack of long-term data. The quantity and quality of data are insufficient to statistically evaluate limnological trends in $\mathrm{pH}$, dissolved oxygen, phosphorus and nitrogen compounds, chlorophyll $a$, and other lake-water constituents or properties. Even though it is not possible to statistically document lake water-quality trends, sufficient data or observations, however, have been made since the turn of the century to indicate that the lake has undergone historical changes in terms of algal and sucker populations.

Historical changes in algal population are summarized in table 2. Complaints were made as early as 1906 of excessive algae contaminating ice supplies (Phinney and Peek, 1961). On July 29, 1913, the predominant algae found by Kemmerer and others (1923) was diatoms (Cyclotella and Melosira), and blue-green algae comprised only 12 percent of the total phytoplankton. The first report of the presence of A. flos-aquae in the lake was in 1933; however, during this summer period, A. flos-aquae was not predominant, and green and diatom species of algae also were present (table 2). In the late 1930's, A. flos-aquae were reported to be abundant, but not always the predominant alga (Bonnell and Mote, 1942). By 1957, A.

flos-aquae was the predominant alga during summer and fall, and was 10 times more abundant than observed in the late 30's (Phinney and Peek, 1961). More recent limnological surveys have indicated that $A$. flos-aquae is a near monoculture comprising almost all of the summer bloom species (Coleman and others, 1988).

At one time, spawning runs of suckers from Upper Klamath Lake were large enough to constitute a major food source for Indians and local settlers. The shortnose sucker and Lost River sucker were staples in the diet of the Klamath Tribe for hundreds of years. In the late 1890 's, a cannery was operated for commercial harvest of the Lost River sucker. In the 1960's 
Table 1.--Concentrations of total ammonia and total soluble phosphorus in sediment pore water from Upper Klamath Lake (Data from Gahler and Sanville, 1971)

[Units in milligrams per liter; $\mathrm{P}$ = phosphosus: $\mathrm{N}=$ Nitrogen]

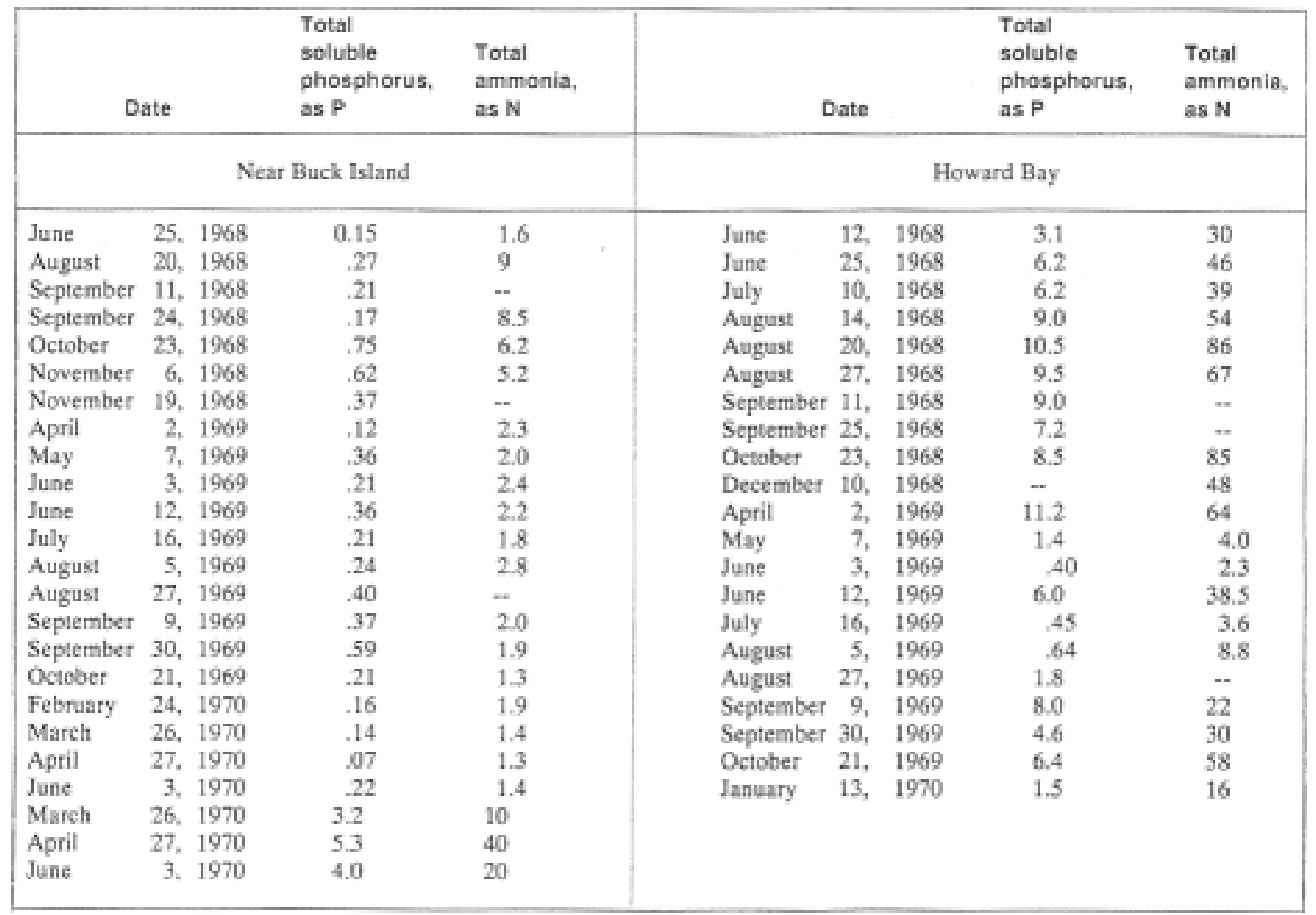

and 1970's, runs of suckers moving from Upper Klamath Lake to the Williamson and Sprague Rivers (fig. 1) were great enough to support a major sport fishery, which attracted many people from throughout the region each year (Federal Register, July 18, 1988). Bienz and Ziller (1987) indicated a drastic decline in the population of Lost River sucker, from an extremely high abundance at the turn of the century to population levels of only 1,000 to 10,000 fish by 1984 in the Williamson and Sprague Rivers. A post fish-kill survey by Coleman and others (1988) suggests the 1986 population of shortnose suckers was dominated by older fish, indicating a low recruitment of young fish into the breeding population. The conclusion of Coleman and others (1988) is based on dead suckers examined after a fish kill in the lake in August 1986. Of the 10 fish examined, all were tentatively considered to be greater than 4 years old. Lost River sucker also were aged from the same fish kill (Coleman and others, 1988). Of 190 Lost River suckers examined, less than 10 fish were younger than 16 years old.

\section{POSSIBLE CAUSES OF EXCESSIVE NUTRIENT ENRICHMENT IN UPPER KLAMATH LAKE}

As previously mentioned, the increased abundance and decreased diversity of algae in the lake is relatively recent (tens of decades) and correlates with settlement of the Klamath Basin. According to Wetzel (1983), the most common cause for increased algal abundance in lakes is increased nutrient enrichment by nitrogen and phosphorus compounds. 
Table 2,--Historical changes in algal populations in Upper Klamath Lake

\begin{tabular}{|c|c|c|c|c|}
\hline Year & $\begin{array}{l}\text { Month } \\
\text { or } \\
\text { Season }\end{array}$ & Observation & Reporter(s) & Remarks \\
\hline 1906 & January & $\begin{array}{l}\text { Organic matter in lake ice. Decided green } \\
\text { appearance. }\end{array}$ & $\begin{array}{l}\text { USGS/Berkeley; } \\
\text { J.B. Lippencot }\end{array}$ & $\begin{array}{l}\text { Complaints from users of organic } \\
\text { matter in lake ice }\end{array}$ \\
\hline 1913 & July & $\begin{array}{l}\text { Flourishing phytoplankton. Diatoms dominant; } \\
\text { Cyclotella (diatom); and Melosira (diatom) }\end{array}$ & $\begin{array}{l}\text { Kemmerer and } \\
\text { others, } 1923\end{array}$ & Blue-green oaly 12 -percent \\
\hline 1928 & August & $\begin{array}{l}\text { Mostly Spirogyra (green) with a few Ulothrix } \\
\text { (green); and Chroococcus (blue green) }\end{array}$ & $\begin{array}{l}\text { Oregon State } \\
\text { Board of Health }\end{array}$ & Murky water condition \\
\hline 1933 & Summer & $\begin{array}{l}\text { Anabena spiroides (blue green); Pediastrum } \\
\text { (green); Melasira (diatom); Navicula } \\
\text { (diatom); Microcystis (bluc green); and } \\
\text { Aphanizomeman flos-aquae (blue green) }\end{array}$ & $\begin{array}{l}\text { E. I. Sanbom, } \\
\text { Oregon State } \\
\text { College }\end{array}$ & $\begin{array}{l}\text { Enormous midge populations } \\
\text { prompted this study }\end{array}$ \\
\hline $\begin{array}{l}\text { Late } \\
1930 \mathrm{~s}\end{array}$ & Summer & $\begin{array}{l}\text { Aphanizomenon flos-aquae abundant now, but } \\
\text { not always the predominant algae }\end{array}$ & $\begin{array}{l}\text { Bonnell and } \\
\text { Mote, } 1942\end{array}$ & $\begin{array}{l}\text { Enormous midge popalations } \\
\text { prompted this study }\end{array}$ \\
\hline 1957 & Summer & $\begin{array}{l}\text { Aphanizomenon predominant summer and fall } \\
\text { Aphanizomenon cells now } 10 \text { times those of } \\
\text { Bonnell and Mote (1942) }\end{array}$ & $\begin{array}{l}\text { Phinney and } \\
\text { Peck, } 1961\end{array}$ & $\begin{array}{l}\text { Still lots of diatoms, greens, } \\
\text { and blue-greens; mixed community }\end{array}$ \\
\hline $\begin{array}{l}1960 \mathrm{~s}, \\
1970 s, \\
1980 s\end{array}$ & Summer & $\begin{array}{l}\text { Aphanizomenon blooms of long duration and } \\
\text { intensity }\end{array}$ & $\begin{array}{l}\text { Miller and } \\
\text { Tash, 1967; } \\
\text { Klamath Consulting } \\
\text { Service, } 1983\end{array}$ & $\begin{array}{l}\text { Near monoculture of } \\
\text { Aphanizomenon all summer } \\
\text { and fall }\end{array}$ \\
\hline
\end{tabular}


Described below are 10 hypothetical causes for increased nutrient enrichment of the lake since the Klamath Basin was settled. Both external and internal nutrient loading are plausible causative factors that influence the concentrations of nutrients in the lake. Hypotheses, which are statements of unproven ideas, need to be tested for veracity. The 10 hypotheses are ranked, broadly, according to perceived importance. The hypotheses listed first have the most significance, and the hypotheses listed last have the least significance or lowest priority for testing. The ranking, insofar as possible, is based on evidence. The great paucity of data, however, causes much of the ranking to be based on intuitive hydrologic judgment. Nonetheless, some method was needed to focus agency studies on selected factors thought to be the most influential, because the resources needed to study all possible causes are exceedingly unlikely.

\section{Effects of Disturbed Marsh Drainage on Lake-Water Quality}

Hypothesis 1 - Conversion of marsh to agricultural land has caused the soil to change in character and to release large quantities of nutrients to Upper Klamath Lake by both surfaceand ground-water paths, causing excessive nutrient enrichment of the lake.

Process - Although marshes have been shown to be nutrient sinks in several studies, there is a growing consensus that not all marshes are nutrient sinks, and that patterns of nutrient retention and release from marshes are not consistent from season to season or from year to year (Good and others, 1978; Mitsch and Gosselink, 1986). Nutrients are often bound up in sediment and peat. Decomposition of accumulated organic matter in marshes is slower beneath anaerobic standing water than decomposition of organic matter that is exposed to the atmosphere. Thus, changes in the hydrologic conditions of a marsh, such as the drainage and lowering of the water level, may have an important effect on the nutrient-storage processes. Several studies have shown that when marshes are drained and converted to agricultural lands, the soil changes character owing to oxidative processes that accelerate decomposition of organic matter by the action of aerobic bacteria (Alexander, 1961; Avnimelech, 1971; Broadbent, 1960; Kreitler and Jones, 1975; Levanon and others, 1987; and Maciak, 1966.

When marshes are drained and converted to agricultural lands, organic nitrogen compounds oxidize (aerobically decompose) to nitrate, causing large accumulations of nitrate in the upper layer of soil (Avnimelech, 1971; Kreitler and Jones, 1975; and Levanon and others, 1987). Nitrate is a mobile constituent in water, and its subsequent leaching by irrigation water or precipitation causes nitrate to reach the lake by surface drainage or ground-water contribution.

Dissolved phosphate mineralized from organic phosphorus in marsh soil is less mobile than nitrate and tends to be retained in mineral soils. Phosphorus retention capacity differs greatly among wetland types depending on the mineral content of their soils (Richardson, 1985). Organic-rich sediment is a major part of the peat which forms from decaying plants, but decaying plants also trap detrital mineral matter which becomes an integral part of peat. Richardson found that the retention capacity of phosphorus compounds could be predicted by aluminum and iron content in wetland soils. The release of dissolved phosphate from disturbed marsh, therefore, will depend on the mineral content as well as other geochemical, physical, and biological factors. For example, marsh soils may be artificially limed, causing soil $\mathrm{pH}$ changes that allow the liberation of phosphate and trace elements to agricultural plants.

Phosphate ions are strongly sorbed in acidic soils, but are more readily released in the neutral $\mathrm{pH}$ range which may be caused by liming and more aerobic conditions. If exchange sites on marsh soils become saturated with phosphorus, excess phosphate will be exported from the 
marsh. Physical changes, such as ditching and draining, also can increase the erosion and transport of particulate phosphorus compounds and of dissolved phosphate compounds that cannot filter through the marsh soils.

Earlier gross nutrient budgets for Upper Klamath Lake indicate that about 20 percent of the annual nitrogen input and 26 percent of the phosphorus input to the lake are from agricultural marshland draining directly to the lake (Miller and Tash, 1967). Miller and Tash (1967) considered only surface-water drainage directly to the lake, neglecting ground-water inflow from disturbed marsh. Miller and Tash (1967) also did not quantify nutrient loading due to surface- and ground-water flow from disturbed marshes draining to tributary rivers. Consequently, Miller and Tash (1967) estimated that nutrient input from agricultural marshland could be extremely low. The timing of nutrient inputs also may be important. Nutrient inputs are likely to occur during spring after winter decay of vegetation, with the presence of wetland vegetation. A spring flush of nutrients may be accelerated by cycles of dewatering of wetland areas in the spring by pumping water from drainage ditches to streams feeding the lake.

\section{Agricultural Activities in the Basin}

Hypothesis 2-Agricultural activities in the Klamath Basin have caused greater nutrient loads in streams that flow to the lake.

Process-The Wood and Williamson Rivers that drain into the lake account for 64 percent of the flow, and contribute 43 to 79 percent of all incoming nutrients to the lake. A comparison of the proportion of nutrients from natural with agricultural sources has not been attempted in previous studies. For example, the effect of livestock grazing, the dominant land use in the Sprague River Basin, is not known. The amount of waste material produced by large numbers of cattle is a potential contributor to nutrient loading. Loss of riparian vegetation may also be a factor in nutrient loading.

Fertilizer application to forest and agricultural land can increase nutrient loads to ground water and streams. Fertilizer applied to flood-irrigated land in particular, has a high potential for moving to ground water and streams. Accelerated erosion of upland forest, range, and agricultural land, due to land-use practice, can increase sediment delivery to the lake. This sediment contains organic and inorganic materials with sorbed nutrients that further enrich the lake. Conversion of marsh to agricultural land in these tributary reaches can cause an increase in nutrient loading by mechanisms described in hypothesis 1 .

\section{Effects of Reservoir Regulation on Lake-Water Quality}

Hypothesis 3-Klamath Lake flushing patterns have changed as a result of Link River Dam and stream diversion activities. More runoff is captured from the large flows of spring snowmelt than before the dam was built; thus, more wintertime and springtime nutrients at large flows are captured.

Process-Inorganic and organic particulates entering Upper Klamath Lake during spring snowmelt are more likely to remain in the lake and enhance the internal recycling of nutrients, rather than being flushed through the lake. Perhaps more importantly, after construction of Link River Dam, fewer nutrient-rich particulates settling from the water column to the bed sediment are scoured out and passed downriver during spring high flow. Changes in summer base flow due to stream diversions also are a factor in seasonal flushing of the lake. 
Correlative hypothesis-Whenever the lake level is drawn below its natural summertime low, the lake is more susceptible to wind-induced resuspension of bottom sediment and internal release of nutrients to the water column.

Process-Sediment in lakes is generally characterized by large concentrations of nutrients and other solutes in the sediment pore water. Sediment pore water concentrations of solutes commonly exceed those in overlying water-in some cases by order of magnitude. Large nutrient concentrations in the pore water are due to inorganic and organic detrital accumulations and subsequent metabolism of organic material to soluble forms. Release of nutrients and other solutes to the overlying water is usually controlled by four principle mechanisms: mixing caused by benthic organisms, gas bubbles evolving from sediment, resuspension of bulk sediment by wind-induced turbulence, and molecular diffusion. In shallow lakes characterized by extensive fetches, sediment resuspension is likely to be a major mechanism for internal nutrient cycling. Water depth is one of several variables that ultimately influence wind-induced sediment resuspension.

\section{Changes in the Magnitude and Timing of Nutrient Inflow from Streams}

Hypothesis 4-Stream diversion, flow regulation, and land-use changes have caused changes in magnitude and timing of nutrient inflows to Upper Klamath Lake, thereby enhancing nutrient enrichment of the lake.

Process-Streamflow volumes and stream nutrient loads vary seasonally and with storms. The amount of nutrients and timing of water inflow to the lake commonly change as a result of changes in land-use practices such as urbanization, cultivation, and irrigation. During snowmelt, lowland areas near the lake fill with water behind dikes. Excess water is pumped from drainage ditches into the lake or streams in the spring. As a consequence, water is not filtered naturally through wetland soils before entering the lake. It is not known whether pumped water increases the nutrient load to the lake compared with water that reaches the lake by way of natural gradients. In summer, water is diverted to fields for irrigation. Water that is applied to artificially fertilized fields may become enriched in nutrients during soil infiltration. Infiltrated water, draining back to the stream, may contain large concentrations of nutrients that may enhance algal growth in the lake during the summer.

Although this hypothesis may not be tested directly, it is interrelated with hypotheses 1 and 2 .

\section{Loss of Submersed Rooted Aquatic Plants}

Hypothesis 5-The increasingly abundant growths of blue-green algae in Upper Klamath Lake have reduced light penetration, causing a decline of many submersed rooted aquatic plants. This loss has resulted in the destabilization of bed sediment, making nutrients more available and causing even more abundant algal growth.

Process-Submersed and emergent rooted aquatic plants act as "strainers" to retard movement of particulates in the water column and also as "anchors" for bottom sediment. In contrast, a lakebed devoid of rooted aquatic plants is much more susceptible to resuspension of sediment. Rooted aquatic plants also (indirectly) provide shelter and food for fish. It is not uncommon for submersed rooted aquatic plants to die off in lakes greatly enriched with nutrients. 
According to V. Carter (U.S. Geological Survey, written commun., 1989), increased nutrient concentrations stimulate the growth of submersed rooted aquatic plants up to a point. Further increases in nutrients, however, result in massive increases in algae and epiphyte populations and decreases in submersed rooted plant populations. Eventually, the submersed rooted plants disappear. The cause of the disappearance is complex, but probably involves light limitation. The light limitation probably upsets the photosynthetic balance of the rooted plants and thus their ability to translocate necessary substances, including oxygen, to or from the root tissues.

Many studies have shown the delicate balance and relation that exists between the growth of phytoplankton and rooted aquatic plants. Although greater insight on this relation is needed, an immediate study is not proposed.

\section{Increased Internal Cycling of Nutrients}

Hypothesis 6-Increased internal recirculation of nutrients from the lake bottom sediment to the water column has caused greater nutrient enrichment of Upper Klamath Lake.

Process-Internal recycling of nutrients is an active process in Upper Klamath Lake. The lake is extremely shallow, averaging only $8 \mathrm{ft}$ in depth. It takes only a gentle wind to cause resuspension of bottom sediment. The resuspended sediment releases nutrients to the water column where algae grow. Pore water within the bottom sediment also contains large concentrations of soluble phosphorus and nitrogen (Gahler and Sanville, 1971). These large concentrations of soluble nutrients are primarily the result of plant and animal matter decaying.

An increase in nutrient inflow from any source can result in both increased aquatic plant and animal growth which, at death, results in increased deposition of nutrient-rich matter in the bottom sediment. The increased richness of the bottom sediment can then result in increased internal nutrient recycling. Thus, the stimulatory effects of short-duration nutrients influxes are perpetuated for long periods of time.

There is evidence that in-filling (sedimentation) of the Upper Klamath Lake Basin is not occurring at a fast enough rate to change the mixing characteristics of the lake (Martin and Rice, 1981). This does not mean, however, that wind-induced turbulence and mixing of nutrients from the sediment to the water column have remained unchanged in recent history. Lake impoundment by the Link River Dam in 1921 caused lake levels to go both higher and lower than before. The lower lake levels allow more bottom sediment to resuspend during windy periods, releasing more nutrients into a smaller volume of water. Although internal nutrient cycling is an important process in the nutrient dynamics of the lake, it is not a primary cause of increased nutrient enrichment. Rather, it is a secondary sustaining effect.

Internal cycling is an important process that is difficult to quantify, and because internal cycling is a secondary sustaining effect, it has been given middle ranking for immediate testing.

\section{In-Lake Dredging and Diking Practices}

Hypothesis 7-Nearshore dredging and diking to form and maintain dikes around the reclaimed agricultural land has caused nutrient enrichment of the lake by stirring the bottom sediment and releasing nutrients from the sediment into the water column. 
Process-Dredging and diking of nearshore areas causes resuspension of bottom sediment, and exposes sediment that has been buried for decades or more. This bottom sediment is rich in nutrients that have been converted from organic detritus to soluble forms. Normally, the rate at which the nutrients can enter the water column from the bottom sediment is limited by diffusive processes, and by the depth to which wind action can cause resuspension. Dredging exposes deeper sediment which normally would have far less interchange with the water column, thus enhancing transfer of nutrients to the water column. The movement of sediment by dredging is locally important, but overall sediment transfer by natural, wind-generated processes is probably much more significant. Thus, this hypothesis has not been given a high rank for testing.

\section{Increased Nutrient Loads from Rain and Snow}

Hypothesis 8 - Increased nutrient loads from rain and snow have caused nutrient enrichment of Upper Klamath Lake.

Process-Ultimately, all water within Upper Klamath Lake Basin comes from rainfall or snowfall. Thus, small changes in the chemical character of the rain or snow that falls in this basin can have a large effect on lake-water quality. In areas of the Nation that are affected heavily by industry or automobile traffic, an increase in nitrous oxides emissions have caused rain and snow to carry higher loads of nitrogen.

Storm fronts move from the Pacific Ocean to the Upper Klamath Lake Basin. Along this pathway, rainwater is relatively unaffected by activities of man. The atmospheric contribution of nitrogen from rain or snow appears to have remained relatively stable over time. Although there are no data to confirm this, phosphorus in rain or snow probably has remained stable; but low compared to nitrogen. Phosphorus concentrations in precipitation in the Cascade Range near Portland (fig. 1) ranged from $<0.006$ to $0.016 \mathrm{mg} / \mathrm{L}$ as phosphorus; nitrate nitrogen concentrations were about 10 times larger, ranging from 0.02 to $0.20 \mathrm{mg} / \mathrm{L}$ (Hubbard and others, 1988, p. 309). Reports summarizing the annual precipitation quality, nationwide, as measured by the National Trends Network (NTN) and the National Atmospheric Deposition Program (NADP) [Rinella and Miller, 1988; National Atmospheric Deposition Program/ National Trends Network, 1991] indicate that nitrate and ammonia concentrations in precipitation are among the smallest, nationwide in Washington and Oregon and northernmost California. Line-of-equal concentrations maps of the Nation show concentrations of less than $0.15 \mathrm{mg} / \mathrm{L}$ nitrate nitrogen and less than $0.1 \mathrm{mg} / \mathrm{L}$ ionized ammonia $\left(\mathrm{NH}_{4}{ }^{+}\right)$in Oregon precipitation (National Atmospheric Deposition Program/National Trends Network, 1991). Phosphorus concentrations in precipitation are no longer published annually. NADP data in 1984 indicate precipitation at Silver Lake Ranger Station, west of Upper Klamath Lake Basin, had orthophosphorus (as phosphorus) concentrations ranging from 0.001 to $0.004 \mathrm{mg} / \mathrm{L}$. Such small concentrations would act as a phosphorus diluent for the surface water entering Upper Klamath Lake.

This hypothesis will not be tested because of the relatively low probability of significant increases in phosphorus and nitrogen in precipitation at this location.

\section{Natural Causes}

Hypothesis 9-Upper Klamath Lake is naturally enriched and the changes in algae abundance and type has occurred as a result of natural lake-aging processes. 
Process-In a geologic time scale, all lakes age and die. Even oligotrophic lakes become eutrophic with time and eventually evolve to marsh and then to dry land. The process involves tens, hundreds, and even thousands of years, depending on the depth of the lake, the nutrient and sediment loads that enter the lake, and the physical structure of the lake. Sediment infilling, however, is the dominant aging process. Clearly, when man arrived, the Upper Klamath Lake Basin was in a condition of natural enrichment and shallowness, suggesting that the basin already was near the latter end of the geologic time scale in the aging process. This process, considered individually, implies that man has not caused an increase in nutrient enrichment.

This hypothesis is given a low ranking for testing based on two lines of evidence: the water depth of the lake has not changed measurably over the past 70 years (Martin and Rice, 1981), and existing evidence of man-induced effects. Nutrient loading to Upper Klamath Lake from agricultural activities that drain directly to the lake constitute at least 20 to 26 percent of the surface-water nutrient input to the lake. Considering agricultural inputs to the lake that come first into the major rivers, as opposed to directly into the lake, there is evidence that agricultural drainage is a major source of nutrients to the lake. Evidence also indicates that operation and construction of Link River Dam decreased the flushing ratio of the lake, reducing the spring snowmelt flush of the lake, and retaining more of the particulate and dissolved load of nutrients from the spring snowmelt. Firm data are not yet available, so the evidence is not quantitative, but man-induced lake nutrient enrichment is probably significant, and the effect of nutrients from man's activities may even exceed that from all natural sources.

\section{Nutrient Loads From Waterfowl}

Hypothesis 10-Waterfowl resting and breeding on the lake have caused increased nutrient enrichment of the lake.

Process-Upper Klamath Lake is part of a large complex of wildlife refuges in the Upper Klamath Lake Basin; an estimated 90 to 95 percent of the waterfowl migrating along the Pacific Flyway use this basin. In the Upper Klamath Lake Basin complex, peak numbers of more than a million ducks and geese are not uncommon in late fall (S.K. Sorenson, U.S. Geological Survey, written commun., April 1990). Waste from waterfowl provide a rich source of nutrients to the lake.

Historical use of the area by waterfowl has declined rather than increased over the past few decades, making the nutrient contribution from waterfowl smaller, rather than greater. Because of this waterfowl decline, this hypothesis is not rated high.

\section{POSSIBLE CAUSES OF DECLINE IN SUCKER POPULATIONS}

Described below are 11 hypothetical causes for the decline in resident sucker species. Many interrelated variables can affect the decline of any fish population, but for ease of presentation, each hypothetical cause is discussed independently.

\section{pH Effects}

Hypothesis 1-Prevailing pH conditions in Upper Klamath Lake for much of the year are detrimental to sucker populations.

Process-During times of high algal productivity, water $\mathrm{pH}$ is usually between 9.0 and 10.0 during the daytime. During 1987, the average $\mathrm{pH}$ throughout July and August at nine sites was 10.0. These large $\mathrm{pH}$ values result from the rapid removal and assimilation of dissolved carbon dioxide from the water by algae. These extremely large $\mathrm{pH}$ values are harmful to fish 
(M. Coleman, Klamath Tribe, written commun., September 1988). Juvenile sucker mortality was observed in bioassay tests at pH 10.0 and above (J. Kann, Klamath Tribe, oral commun., September 1988).

The most common upper limit for $\mathrm{pH}$ is 9 ; $\mathrm{pH}$ values between 9 and 10 may be harmful to a few species of fish, especially to the developmental stage of some species (Canadian Council of Resource, 1987). Temporarily, large $\mathrm{pH}$ values often are produced in the euphotic zone of highly productive water. Because these large $\mathrm{pH}$ values often prevail for only a few hours, they do not produce the harmful effects of sustained high $\mathrm{pH}$ levels.

Because of the documentation of instantaneous $\mathrm{pH}$ values of 10 and higher during summer, this hypothesis ranks high for testing. Continuous monitoring of $\mathrm{pH}$ and related variables, such as dissolved oxygen, is needed to determine the temporal persistence of high $\mathrm{pH}$ during the summertime and spatial patterns. This monitoring would need to be followed by a careful design of bioassay tests that take into consideration influences of other variables.

\section{Ammonia Effects}

Hypothesis 2-Large concentrations of free ammonia, resulting from large nutrient loads to the lake, and high $\mathrm{pH}$ values in the lake, are causing poor survival of the sucker population.

Process.-Pore water in Upper Klamath Lake has large concentrations of dissolved ammonia (table 1). During times of wind mixing, when bottom sediment is resuspended, large concentrations of ammonia from the pore water mix with the lake water. Fish are quite insensitive to $\mathrm{NH}_{4}{ }^{+}$, but un-ionized ammonia $\left(\mathrm{NH}_{3}\right)$, is toxic to them even at small concentrations. Concentrations of ammonia acutely toxic to fish may cause loss of equilibrium, hyperexcitability, increased breathing, cardiac output and oxygen uptake; and in extreme cases, convulsions, coma, and death. At lower concentrations, ammonia has many effects on fish, including a reduction in hatching success, a reduction in growth rate and morphological development, and pathologic changes in tissues of gills, livers, and kidneys (U.S. Environmental Protection Agency, 1986).

Ammonia changes proportion between its ionized and un-ionized forms, depending on water $\mathrm{pH}$ and temperature. Even though toxic $\mathrm{NH}_{3}$ comprises a higher percentage of the total ammonia at higher $\mathrm{pH}$ and higher temperature, fish are more sensitive to toxic effects of un-ionized ammonia at lower pH (U.S. Environmental Protection Agency, 1986).

Concentrations of $\mathrm{NH}_{3}$ in the range of 0.14 to $4.6 \mathrm{mg} / \mathrm{L}$ have been shown to be toxic to several species of nonsalmonid fish (U.S. Environmental Protection Agency, 1986). About 1.0 $\mathrm{mg} / \mathrm{L}$ of $\mathrm{NH}_{3}$ is actually lethal to most fish species. Concentrations of even total ammonia seldom reach such levels naturally, unless anaerobic conditions persist and nitrification is impeded (Welch, 1980). In 1981, water-column concentrations of total ammonia ranged from 0.08 to $1.2 \mathrm{mg} / \mathrm{L}$ in July and August from eight sites in the Upper Klamath Lake (Klamath Consulting Service, 1983). At $25^{\circ} \mathrm{C}$ and $\mathrm{pH} 9$, a concentration of $0.08 \mathrm{mg} / \mathrm{L}$ total ammonia is toxic to salmonids and other sensitive cold-water fish (U.S. Environmental Protection Agency, 1986). No toxic concentrations are given for warm-water fish species in the above reference.

The importance of $\mathrm{pH}$ is explained in the example below. At $20^{\circ} \mathrm{C}$ and $\mathrm{pH} 7.0$, a total ammonia concentration $\left(\mathrm{NH}_{3}+\mathrm{NH}_{4}{ }^{+}\right)$of $5.1 \mathrm{mg} / \mathrm{L}$, a concentration typical of bottom-sediment pore water (table 1), contains only $0.020 \mathrm{mg} / \mathrm{L}$ un-ionized $\mathrm{NH}_{3}$. At the same temperature, but at $\mathrm{pH} 10$, however, the same total ammonia concentration of $5.1 \mathrm{mg} / \mathrm{L}$ contains $4.1 \mathrm{mg} / \mathrm{L}$ un-ionized $\mathrm{NH}_{3}$, which is well above $1.0 \mathrm{mg} / \mathrm{L} \mathrm{NH}_{3}$ that is toxic to most fish species. Ammonia toxicity also is influenced by dissolved-oxygen concentration, temperature, previous 
acclimation to ammonia, fluctuating or intermittent exposures, carbon-dioxide concentration, salinity, and the presence of other toxicants (U.S. Environmental Protection Agency, 1986). For example, ammonia toxicity is enhanced by low dissolved oxygen (Canadian Council of Resource, 1987).

The large concentrations of ammonia in lake and pore water, combined with small dissolved-oxygen concentrations and high $\mathrm{pH}$ values in overlying water, suggest testing of this hypothesis be ranked high.

\section{Hypoconcentrations or Hyperconcentrations of Dissolved Oxygen}

Hypothesis 3-Inadequate concentrations of dissolved oxygen in Upper Klamath Lake are causing poor survival of sucker populations.

Process-Aquatic plants and animals, especially fish, are adversely affected by oxygen depletion; certain minimum levels of oxygen are needed to maintain healthy conditions. A lower level of $4 \mathrm{mg} / \mathrm{L}$ of dissolved-oxygen concentration is needed to avoid acute mortality of nonsalmonid fish in early life stages (U.S. Environmental Protection Agency, 1986). Sublethal and lethal effects of varying concentrations of dissolved oxygen, ammonia, and $\mathrm{pH}$ values need to be studied together.

Dissolved-oxygen depletion usually occurs in the summertime, during the die off of algal blooms, and in the winter under ice cover. Wide daily variations in dissolved-oxygen concentration occur in highly enriched lakes as algae produce oxygen by photosynthesis in the daytime, releasing oxygen into the water, and often creating supersaturated conditions. Supersaturation may cause gas-bubble trauma in fish; supersaturation of 150 percent with respect to dissolved oxygen has been reported detrimental to fish (McKee and Wolf, 1963). In July and August of 1981 and 1982, 15 out of 105 dissolved-oxygen measurements in Upper Klamath Lake indicated greater than 150 percent of dissolved-oxygen saturation (Klamath Consulting Service, 1983). At nighttime, no oxygen is produced, but the algae continue to respire, causing a net loss of oxygen in the water. In 1987, dissolved-oxygen concentrations were depressed at times to less than $1.0 \mathrm{mg} / \mathrm{L}$ during the daytime near the lake bottom, and dissolved-oxygen concentrations between 3.0 and $5.0 \mathrm{mg} / \mathrm{L}$ were not uncommon in the upper part of the water column (Coleman and others, 1988).

This is an important hypothesis to test and is ranked high priority with the previous hypothesis. Some insight as to the effects of small dissolved-oxygen concentrations on increasing ammonia toxicity will be gained when testing hypothesis 2 .

\section{Loss of Refuge Areas}

Hypothesis 4-Upper Klamath Lake has lost much of its summertime fish refuge area, causing poor sucker survival.

Process-Historical marsh shoreline, stream distributaries, and nearshore springs may have been a refuge area for many fish species during extensive algal blooms. Loss of these refuge areas has occurred because of at least three factors: (1) altering natural shoreline and stream distributaries by diking, (2) periodic dredging and diking activities that suspend the bottom sediment and, (3) decreased lake levels in the summertime because of irrigation drawdown, which causes inlets and embayments to shrink in size. Habitat needs are critically important to fish survival. This hypothesis ranks middle to high for testing. A comprehensive

inventory of land use, stream channel, and shoreline changes is needed to assess the historical loss of refuge areas. 


\section{Loss of Spawning and Rearing Areas}

Hypothesis 5-Loss of spawning gravels and spawning areas are a major cause of poor survival of sucker populations in Upper Klamath Lake.

Process-The shortnose sucker and Lost River sucker depend primarily on river habitat for spawning and rearing (Bienz and Ziller, 1987). Spawning also occurs in areas of large springs along the shores of Upper Klamath Lake. For example, historically there were massive spawning migrations of Lost River suckers into Harriman Spring in Pelican Bay (J. Kann, Klamath Tribe, written commun., 1991). Much of the historical spawning grounds in the Upper Klamath Lake Basin have been blocked by the construction of a dam on the Sprague River near Chiloquin, Oregon (fig. 1). The dam is located just upstream of the junction of the Sprague and Williamson Rivers and probably eliminated 95 percent of historical spawning habitat (Federal Register, 1988). Fish ladders have been constructed at various times on the dam on the Sprague River, but their effectiveness in facilitating movement of suckers around the structure has been minimal. Stream channel habitat was lost by the diking of lower Williamson River and replacing its former distributaries.

Extensive periphytic bottom growth chokes the lower Sprague River channel during the summer months. It is unknown how much this growth affects spawning or rearing. Studies in the Truckee River, Nevada, by Hoffman and Scoppettone (1988) showed that periphytic bottom growth reduced oxygen exchange in intragravel water to the point that fish-egg survival was greatly reduced.

Hypotheses 4 and 5 are at least as important as hypotheses 1, 2, and 3, but are ranked middle to high priority for testing because they can be done at any time using historical records. These hypotheses are important to test by inference because of the impact of habitat reduction.

\section{Algal Toxins}

Hypothesis 6-The near monoculture of the blue-green algae, A. flos-aquae, releases a toxin that is causing poor sucker survival.

Process-Events of algal toxicity to animals and fish have been reported worldwide. Fish exposed to algal toxins have been described as struggling, stupefied, stunned, and lethargic. Many appear to have breathing difficulties and spatial disorientation, and may float belly up before dying. A. flos-aquae is one of several algal species often incriminated in apparent toxicity events ascribed to algal blooms (McKee and Wolf, 1963). More often, however, fish kills are the result of a lack of oxygen in the water, rather than direct algal toxicity caused by the rapid decomposition of algae.

This hypothesis is ranked relatively high because of the potential release of toxins from massive A. flos-aquae blooms that may be affecting sucker populations.

\section{Temperature Effects}

Hypothesis 7-High temperatures in Upper Klamath Lake are causing poor sucker survival.

Process.--Upper Klamath Lake is a sprawling body of water with an extremely shallow depth in proportion to its surface area. Summertime water temperatures usually range from 21 to $25^{\circ} \mathrm{C}$, but at times, reach as high as $30^{\circ} \mathrm{C}$ in surface scums. The lake is readily mixed from top to bottom by the gentlest of winds because of its shallow depth. Summertime temperature 
differences between lake surface and bottom are usually 2 to $4{ }^{\circ} \mathrm{C}$, and any temperature gradient that develops is quickly eliminated by mild wind action. The water temperature regime of a lake affects the community structure and geographic distribution of aquatic species. Decreases in summertime baseflows of the major rivers and small streams that drain into the lake probably result in increased water temperatures in the nearshore areas of the lake.

The overall temperature regime of the water body probably has not changed significantly in recent decades because climate and lake depth are relatively constant (Martin and Rice, 1981). Nonetheless, possible temperature changes nearshore due to changes in land use and in the main water body due to reservoir regulation may be significant and deserving of testing as a middle-ranked priority. Testing of hypothesis 4 may provide some insight into temperature effects in nearshore areas.

\section{Feeding Effects}

Hypothesis 8-Changes in Upper Klamath Lake have resulted in the loss of a necessary food source or the ability of the sucker to feed, causing poor survival.

Process-Reduced availability of food sources to the fish would result in fewer adult fish and lower juvenile recruitment. As Upper Klamath Lake changes character, due to excessive nutrient supply and algal blooms, the diversity and biomass of benthic animals, a food source for suckers, may change. These changes in food source or supply may result in poor survival of the sucker population. Larval and juvenile suckers of all species are probably zooplanktivorous, but shortnose sucker are probably mid-water zooplanktivorous throughout their lives (J. Kann, Klamath Tribe, written commun., 1991). Decreased visibility due to massive algal blooms may effect feeding by decreasing prey availability. Mechanical interference with gill functions is another effect of algal blooms (J. Kann, Klamath Tribe, written commun., 1991). This hypothesis has been ranked low for testing, because changes in diversity and abundance of benthic animals and of prey selection are probably secondary effects triggered by shifts in the trophic condition of the lake.

\section{Disease or Predation Caused by Exotic Species}

Hypothesis 9-Disease or predation is causing poor survival of suckers.

Process-Exotic fish, such as fathead minnows and yellow perch, have been stocked in the Upper Klamath Lake Basin (Federal Register, 1988) and could be a source of parasites or disease. Fathead minnows were first documented in the Klamath River system in 1974 and have spread to the most abundant species of fish in Upper Klamath Lake (Federal Register, 1988). The minnows may compete with the sucker for food, and yellow perch are potential predators on larval sucker.

This hypothesis is potentially important to test. The low rank is due in part to the lack of adequate historical scientific data on predator-prey relations in the lake.

\section{Overharvest}

Hypothesis 10.-Overharvest is the cause of poor sucker survival.

Process-The sucker population decreases because of increased harvesting to some critical point at which the species has difficulty recruiting enough young to perpetuate itself. A period of more rapid population decline follows and, if unchecked, leads to extinction. Because the fish have a high reproductive potential and were extremely abundant historically, overharvest probably is not a main reason for the decline (J. Williams, U.S. Fish and Wildlife 
Service, Endangered Species Program, oral commun., July 1989). Furthermore, harvesting has been banned, but the sucker species have not recovered. Because of the above opinion, this hypothesis has been given low priority for testing.

\section{Pesticide Residues}

Hypothesis 11 -Pesticide residues from agricultural activity in the basin have accumulated in the bottom sediment of Upper Klamath Lake and enter the food chain by sediment resuspension. These large residue concentrations are causing poor sucker survival.

Process-Some pesticides, such as organochlorine compounds, are known for their widespread historical and current use, greater stability, and toxicity. A major concern is the environmental accumulation; in particular, the biological magnification of pesticides in the food web. Some of the older-generation pesticides, such as DDT, are particularly resistant to degradation. DDT has several metabolites (Rinella and others, 1993); the two most frequently found in nature are dichlorodiphenyldichloroethane (DDD) and

dichlorodiphenyltrichloroethylene (DDE). DDT and its metabolites are concentrated by aquatic organisms at all trophic levels. In a reconnaissance investigation of water, bottom sediment, and biota in the lower Klamath Lake area, organochlorine compounds were detected in most samples and in all media sampled (Sorenson and Schwarzbach, 1991). Concentrations of DDE were the largest and most widespread. DDD concentrations were unusually large in eggs of western grebes from Tule Lake.

This is an important hypothesis to test. It is ranked low priority here because of the ongoing study to assess the effect of pesticide inputs on the health and status of the fish population in the Klamath Basin. Studies completed by Sorenson and Schwarzbach (1991) indicate the presence of DDT and its metabolites in some species of waterfowl. A more intensive, follow-up phase to this study will include expanded sampling of fish species in the lower Klamath Lake area.

\section{SUMMARY}

Upper Klamath Lake is characterized by excessive nutrient enrichment and dense, long-duration, algal blooms of A. flos-aquae. In 1988, the Lost River sucker (Deltistes luxatus) and shortnose sucker (Chasmistes brevirostris), which historically have constituted an important part of the lake fishery, were placed on the Federal Endangered Species List. The endangerment of the sucker species in recent years is hypothesized to be caused by degradation of lake-water quality.

Although several reconnaissance studies and some process studies have been done in the Upper Klamath Lake, these studies provide little insight for answering the questions posed by the 21 hypotheses presented. The data from these studies were extremely important in formulating of the hypotheses and providing a general description of the lake and the sediment quality in the Lake. These former studies were not, however, designed to test hypotheses. Future studies by the U.S. Geological Survey and other agencies may be oriented toward answering one or more of the hypotheses presented.

Hypotheses have been given priorities in this report to provide a focus for study with limited resources available. The hypotheses with highest priorities for testing are: (1) the conversion of marsh to agricultural land that has caused the soil to change in character and to release large quantities of nutrients to Upper Klamath Lake by both surface- and ground-water paths, causing excessive nutrient enrichment, (2) agricultural activities in the basin that have caused greater nutrient loads in streams that flow to the lake, and (3) lake flushing patterns that 
have changed as a result of Link River Dam and stream diversion activities. More runoff is captured from the large flows of spring snowmelt than before the dam was built; thus, more wintertime and springtime nutrients at large flows are captured.

Hypotheses for priority testing relating directly to sucker species survival are (1) prevailing $\mathrm{pH}$ conditions (approximately a $\mathrm{pH}$ of 10 during growing season) are detrimental to sucker survival; (2) large concentrations of free ammonia, that result from large nutrient loads, and high $\mathrm{pH}$ values in the lake are causing poor survival of the sucker population; and (3) inadequate concentrations of dissolved oxygen in Upper Klamath Lake are causing poor survival of sucker populations. 


\section{SELECTED REFERENCES}

Alexander, M., 1961, Introduction to soil microbiology: New York and London, John Wiley and Sons, Inc., 323 p.

American Public Health Association, American Water Works Association, and Water Pollution Control Federation, 1985, Standard methods for the examination of water and wastewater (16th ed): Washington, D.C., 1268 p.

Avnimelech, Yoram, 1971, Nitrate transformation in peat: Soil Science, v. 111, no. 2, p. 113-118.

Bienz, C.S., and Ziller, J.S., 1987, Status of three lacrustrine sucker species (Catostomidae): Joint report by the Klamath Tribe and Oregon Department of Fish and Wildlife, 39 p.

Bond, C.E., Hazel, C.R., and Vincent, D., 1968, Relations of nuisance algae to fishes in Upper Klamath Lake: Terminal progress report by the U.S. Federal Water Pollution Control Administration Research Grant WP 00625, Oregon State University, Department of Fisheries and Wildlife, Corvallis, Oregon, 120 p.

Bonnell, D.E., and Mote, D.C., 1942, Biology of the Klamath midge, Chironomus utahensis in Proceedings of the B.C. Ent. Society, v. 39, p. 3-7.

Broadbent, F.E., 1960, Factors influencing the decomposition of organic soils in the California delta: Hilgardia, v. 29, no. 13 , p. $587-612$.

Bue, C.D., 1963, Principal lakes of the United States: U.S. Geological Survey Circular 476, 22 p.

Canadian Council of Resource and Environment Ministers, 1987, Canadian Water Quality Guidelines: Environment Canada, Ottawa, Ontario, paginated by chapter.

Carlson, R.E., and Schoenberg, S.A., 1983, Controlling blue-green algae by zooplankton grazing: lake restoration, protection and management: U.S. Environmental Protection Agency 440/5-83-001, p. 228-233.

Carper, G.L., and Bachmann, R.W., 1984, Wind resuspension of sediments in a prairie lake: Canadian Journal of Fisheries and Aquatic Sciences, v. 41, p. 1763-1767.

Coleman, M.E., Kann, J., and Scoppettone, G.G., 1988, Life history and ecological investigations of catostomids from the Upper Klamath Lake basin, Oregon: Annual draft report, U.S. Fish and Wildlife Service, National Fisheries Research Center, Seattle, Wash., 113 p.

Federal Register, 1988, Endangered and threatened wildlife and plants; determination of endangered status for the shortnose sucker and Lost River sucker: Department of Interior, Fish and Wildlife Service, July 18, 1988, v. 53, no. 137 , p. $27130-27134$.

Gahler, A.R., Sanville, W.D., 1971, Lake sediments: Characterization of lake sediments and evaluation of sediment-water nutrient interchange mechanisms in the Upper Klamath Lake system: U.S. Environmental Protection Agency, Pacific Northwest Water Laboratory, Corvallis, Oregon, 40 p.

Gilbert, G.K., 1928, Studies of basin-range structure: U.S. Geological Survey Professional Paper 153, 92 p.

Good, R.E., Whigham, D.F., Simpson, R.L., 1978, Freshwater wetlands ecological processes and management potential: Academic Press, Inc., 378 p.

Hazel, C.R., 1969, Limnology of Upper Klamath Lake, Oregon with emphasis on benthos: Ph.D. thesis, Oregon State University, Corvallis, Oregon, 184 p.

Hamilton, D.P., and Mitchell, S.F., 1988, Effects of wind on nitrogen, phosphorous, and chlorophyll $a$ in a shallow New Zealand lake: Proceeding (International Association of Theoretical and Applied Limnology) Verh. Internat. Verein. Limnol., v. 23, p. 624-628. 


\section{SELECTED REFERENCES-Continued}

Hoffman, R.J., and Scoppettone, G.G., 1988, Effect of water quality on survival of Lahontan cut-throat trout eggs in the Truckee River, West-Central Nevada and Eastern California: U.S. Geological Survey Water-Supply Paper 2319 , p. 21.

Hubbard, L.E., 1970, Water budget of Upper Klamath Lake southwestern Oregon: U.S. Geological Survey Hydrologic Investigations Atlas HA-351, 2 plates.

Hubbard, L.E., Herrett, T.A., Kraus, R.L., and Moffatt, R.L., 1988, Water- Resources Data Oregon, water year 1988: U.S. Geological Survey Water-Data Report OR-88-2, 320 p.

Kemmerer, G., Bovard, J.F., and Boorman, W.R., 1923, Northwestern lakes of the United States: Biological and chemical studies with reference to possibilities in production of fish: Bulletin of the U.S. Bureau of Fisheries, Document No. 944, p. 75-137.

Klamath Consulting Service, Inc., 1983, The Upper Klamath Lake: EPA 314 Clean lakes program, 1981-1983, Phase 1: Diagnostic/feasibility study: U.S. Environmental Protection Agency, 145 p.

Kreitler, C.W., and Jones, D.C., 1975, Natural soil nitrate: The cause of the nitrate contamination of ground water in Runnels County, Texas: Ground Water, v. 13, no. 1, p. 53-61.

Levanon, D., Levin, I., Kipnis, T., and Cohen, U., 1987, The effect of high yielding perennial herbage crops on biological degradation and nitrate accumulation in peat soil: Experimental Agriculture, v. 23, p. 69-74.

Maciak, F., 1966, Relationship between total and amino nitrogen content and the composition of amino acids for peat-forming plants and in peats: Ekologia Polska, v. 14, no. 11, p. 193-202.

Martin, E.A., and Rice, C.A., 1981, Pb-210 geochronology and trace metal concentrations of sediments from Upper Klamath Lake and Lake Ewauna, Oregon: Northwest Science, v. 55, no. 4, p. 269-280.

McKee, J.E., and Wolf, H.W., 1963, Water quality: California State Water Quality Control Board, Publication No. 3-A, $548 \mathrm{p}$.

Miller, W.E., and Tash, J.C., 1967, Interim report, Upper Klamath Lake studies, Oregon: Federal Water Pollution Control Administration, Pacific Northwest Water Laboratory, Corvallis, Oregon, 37 p.

Mitsch, W.J., and Gosselink, J.G., 1986, Wetlands: Van Nostrand Reinhold, New York, 539 p.

National Atmospheric Deposition Program/National Trends Network, 1991, NADP/NTN Annual Data Summary, Precipitation Chemistry in the United States 1990: NADP/NTN Coordination Office, Fort Collins, Colorado, $475 \mathrm{p}$.

Perdue, E.M., Lytle, C.R., Sweet, M.S., Sweet, J.W., 1981, The chemical and biological impact of Klamath Marsh on the Williamson River, Oregon: Report WRRI-71 Portland State University, Portland, Oregon, 199 p.

Phinney, H.K., and Peek, C.A., 1961, Klamath Lake, an instance of natural enrichment: Transactions of the seminar on algae and metropolitan wastes, April 27-29, 1960, U.S. Public Health Service, p. 22-27.

Phinney, H.K., Peek, C.A., and McLachlan, J.L., 1959, A survey of the phytoplankton problems in Klamath Lake: Report to the supporting agencies, Corvallis, Oregon, $52 \mathrm{p}$.

Rast, Walter, and Lee, G.F., 1978, Summary analysis of North American (U.S. portion), OECD Eutrophication project: Nutrient loading-lake response relationships and trophic indices: EPA-600/3-78-008, Ecological Research Series, $455 \mathrm{p}$. 


\section{SELECTED REFERENCES-Continued}

Rettig, S.A., and Bortleson, G.C., 1983, Limnological study of Shasta Lake, Shasta County, California, with emphasis on the effects of the 1977 drought: U.S. Geological Survey Water-Resources Investigations Report $82-4081,61 \mathrm{p}$.

Richardson, C.J. 1985, Mechanisms controlling phosphorus retention capacity in freshwater wetlands: Science, v. 228, p. 1424-1427.

Rinella, J.F., and Miller, T.L., 1988, Distribution and variability of precipitation chemistry in the conterminous United States, January through December 1983: U.S. Geological Survey Open-File Report 87-558, 241 p.

Rinella, J.F., Hamilton, P.A., and McKenzie, S.W., 1993, Persistence of the DDT pesticide in the Yakima River Basin, Washingon: U.S. Geological Survey Circular 1090, 24 p.

Sallantaus, T., 1988, Water quality of peatlands and man's influence on it in Proceedings of the Symposium on the Hydrology of Wetlands in the Temperate and Cold Regions, Joensuu, Finland, June 6-8, 1988, v. 2, p. 80-98.

Shaw, J.F.H., and Prepas, E.E., 1989, Temporal and spatial patterns of porewater phosphorus in shallow sediments, and its potential transport into Narrow Lake, Alberta: Canadian Journal of Fisheries and Aquatic Sciences, v. 46, p. 981-988.

Sorenson, K., and Schwarzbach, S.E., 1991, Reconnaissance investigation of water quality, bottom sediment, and biota associated with irrigation drainage in the Klamath basin, California and Oregon, 1988: U.S. Geological Survey Water-Resources Investigations Report 91-4203, 64 p.

Stewart, A.J., and Wetzel, R.G., 1982, Influence of dissolved humic materials on carbon assimilation and alkaline phosphatase activity in neutral algal-bacterial assemblages: Freshwater Biology, v. 12, p. 369-380.

Urban, N.R., Bayley, S.E., and Eisenreich, S.J., 1989, Export of dissolved organic carbon and acidity from peatlands: Water-Resources Research, v. 25, no. 7, p. 1619-1628.

U.S. Army Corp. of Engineers, 1982, Upper Klamath Lake, Oregon - Water resources development project: Prepared for U.S. Army Corps of Engineers, San Francisco District, Entranco Engineers, Bellevue, Washington, unpaginated.

U.S. Environmental Protection Agency, 1976 (1977), Quality criteria for water: U.S. Government Printing Office, $256 \mathrm{p}$.

U.S. Environmental Protection Agency, 1986, Quality criteria for water 1986: EPA 440-5-86-001, unpaginated.

Vincent, D.T., 1968, The influence of some environmental factors of the distribution of fishes in Upper Klamath Lake: Corvallis, Oregon, Oregon State University, Masters thesis, 75 p.

Welch, E.B., 1980, Ecological effects of wastewater: Cambridge University Press, 337 p.

Welch, E.B., DeGasperi, C.L., and Spyridakis, D.E., 1988, Source for internal P loading in a shallow lake, Proceeding (International Association of Theoretical and Applied Limnology) Verh. Internat. Verein. Limnol., v. 23, p. 307-314.

Wetzel, R.G., 1983, Limnology: (2d ed.), Saunders College Publishing, 767 p.

Winter, T.C., LaBaugh, J.W., and Rosenberry, D.O., 1988, The design and use of a hydraulic potentiomanometer for direct measurement of differences in hydraulic head between ground water and surface water: Limnology and Oceanography, v. 33, no. 5, p. 1209-1214. 